\title{
Efficacy of a recombinant single-chain fragment variable region, VasSF, as a new drug for vasculitis [Corrigendum]
}

Kameoka Y, Kishi F, Koura M, et al. Drug Des Devel Ther. 2019;13:555-568.

The authors have advised that there was an error in the text.

Page 561, beginning at the left-hand bottom of the page, "The number of peripheral blood lymphocytes and granulocytes did not change in the aVAP2-administered mice: WBCs: $4.42(1.36-7.57) \times 10^{9} \quad$ cells/L vs 3.14
$(1.48-15.7) \times 10^{9}$ cells/L (Figure S3A). The number of granulocytes decreased: $0.15(0.05-1.04) \times 10^{9}$ cells/L vs $0.22(0.04-0.69) \times 10^{9} \quad$ cells/L (Figure S3B)." should instead read "The number of peripheral blood lymphocytes and granulocytes did not change in the aVAP2administered mice: WBCs: $2.11(1.36-2.44) \times 10^{9}$ cells $/ \mathrm{L}$ vs $3.14(1.48-15.7) \times 10^{9}$ cells/L (Figure S3A). The number of granulocytes decreased: $0.055(0.03-0.08) \times 10^{9}$ cells $/ \mathrm{L}$ vs $0.22(0.04-0.69) \times 10^{9}$ cells/L (Figure S3B)."

\section{Publish your work in this journal}

Drug Design, Development and Therapy is an international, peerreviewed open-access journal that spans the spectrum of drug design and development through to clinical applications. Clinical outcomes, patient safety, and programs for the development and effective, safe, and sustained use of medicines are a feature of the journal, which has also been accepted for indexing on PubMed Central. The manuscript management system is completely online and includes a very quick and fair peer-review system, which is all easy to use. Visit http://www. dovepress.com/testimonials.php to read real quotes from published authors. 